\title{
Efektivitas Pendekatan PMRI dengan Konteks Nasi Tumpeng pada Materi Volume Kerucut di Kelas IX
}

\author{
${ }^{1}$ Fentika Rahmadona, ${ }^{2}$ Helni Indrayati, ${ }^{3}$ Indah Widyaningrum \\ ${ }^{1}$ Mahasiswa STKIP Muhammadiyah Pagaralam \\ ${ }^{2,3}$ Dosen STKIP Muhammadiyah Pagaralam \\ ${ }^{1}$ fentikarahmadona@gmail.com, ${ }^{2}$ helniindrayati@yahoo.com, \\ 3indah19850105@yahoo.co.id
}

\begin{tabular}{l}
\hline \hline Article Info \\
\hline Article history: \\
Received July $26^{\text {th }}, 2019$ \\
Revised Sept $3^{\text {rd }}, 2019$ \\
Accepted Nov 14 $14^{\text {th }}, 2019$ \\
\hline
\end{tabular}

Keywords:

Effectiveness;

PMRI;

Learning Outcomes
Abstract

The purpose of this study was to determine the effectiveness of the PMRI approach with the context of cone rice on cone volume material on student learning outcomes in class IX of SMP Negeri 1 Pagaralam 2018/2019 academic year. The method used in this study was True-Experimental Design with a pre-test design posttest control group design. Sample of students including 30 students in the experimental class $\left(I X_{H}\right)$ and 32 control class students $\left(I X_{I}\right)$. The data collection techniques used were test and documentation. To measure student mathematics learning outcomes in this study used a written test in the form of essays totaling five questions. The hypothesis of the research is PMRI's approach to the context of cone rice in cone volume material is effective on student learning outcomes in class IX of SMP Negeri 1 Pagaralam 2018/2019 academic year. The results of students' mathematics test data using the PMRI approach with the context of cone rice on cone volume material on student learning outcomes in class IX of SMP Negeri 1 Pagaralam in the 2018/2019 academic year were obtained from the average.

\section{Kata Kunci: \\ Efektivitas; \\ PMRI; \\ Hasil Belajar}

\begin{abstract}
Abstrak
Tujuan penelitian ini adalah untuk mengetahui keefektivan pendekatan PMRI dengan konteks nasi tumpeng pada materi volume kerucut terhadap hasil belajar siswa di kelas IX SMP Negeri 1 Pagaralam
\end{abstract}


tahun pelajaran 2018/2019. Metode yang digunakan dalam penelitian ini adalah True-experimental Design dengan bentuk desain pretest-posttest control group design. Sample terdiri dari 30 siswa kelas eksperimen $\left(\mathrm{IX}_{\mathrm{H}}\right)$ dan 32 siswa kelas kontrol $\left(\mathrm{IX}_{\mathrm{I}}\right)$. Teknik pengumpulan data yang digunakan yaitu tes dan dokumentasi. Untuk mengukur hasil belajar matematika siswa dalam penelitian ini digunakan tes tertulis yang berbentuk essay yang berjumlah lima soal. Adapun hipotesis dari penelitian adalah pendekatan PMRI dengan konteks nasi tumpeng pada materi volume kerucut efektif terhadap hasil belajar siswa di kelas IX SMP Negeri 1 Pagaralam tahun pelajaran 2018/2019. Hasil data tes matematika siswa dengan menggunakan pendekatan PMRI dengan konteks nasi tumpeng pada materi volume kerucut terhadap hasil belajar siswa di kelas IX SMP Negeri 1 Pagaralam tahun pelajaran 2018/2019 didapat dari rata-rata.

\section{PENDAHULUAN}

Menurut Martin (2012), volume adalah isi atau penghitungan seberapa banyak ruang yang bisa ditempati dalam suatu objek. Sedangkan kerucut adalah bangun ruang sisi lengkung yang menyerupai limas segi- $n$ beraturan yang bidang alasnya berbentuk lingkaran. Jadi, volume kerucut adalah isi atau penghitungan seberapa banyak ruang yang ada pada bangun ruang sisi lengkung yang menyerupai limas segi- $n$ beraturan yang bidang alasnya berbentuk lingkaran. Menurut Syabana (2013) menyatakan bahwa volume suatu bangun ruang dapat dikenali dengan cara menelusuri bentuk alasnya.

Pada hakekatnya suatu bangun ruang berasal dari susunan luas alas yang membentuk tinggi bangun ruang tersebut. Apabila terdapat bangun ruang lain yang tidak beraturan, maka dicoba untuk membentuk sketsanya sehingga dapat dikenali bentuk alasnya. Dengan menganggap bangun ruang ini mengalami perubahan bentuk dari bentuk normalnya, maka perlu ditelusuri mana bentuk alasnya dan menentukan mana tingginya. Dengan cara ini, dapat ditentukan rumus volume bangun ruang tersebut. 
Curry \& Outhred (2005) mengemukakan bahwa volume dapat diukur dengan dua cara yakni dengan cara Filling dan Packing. Filling adalah dengan cara ruang diisi dengan iterasi unit cairan. Dalam metode ini, struktur unit disusun dengan satu dimensi. Packing adalah cara ruang dikemas dengan susunan tiga dimensi secara berulang dalam dimensi tiga.

Menurut Irmayanti (2017) masalah hasil belajar yang masih rendah, khususnya pada kompetensi dasar bangun ruang sisi lengkung, terdapat pula kendala dalam proses pembelajaran, contohnya selama proses pembelajaran berlangsung hanya sedikit siswa yang berani bertanya kepada guru, hanya sedikit siswa yang berani mengajukan diri untuk mengerjakan soal ke depan kelas kecuali ditunjuk oleh guru, saat pembelajaran berlangsung banyak siswa yang tidak tahu beberapa istilah matematika atau pengetahuan prasyarat yang sebenarnya didapatkan pada pelajaran sebelumnya, pembelajaran matematika di kelas masih berjalan monoton, belum ditemukan strategi pembelajaran yang tepat, belum ada kolaborasi antara guru dan siswa, model pembelajaran yang digunakan bersifat konvensional. Untuk itu penelitian mengubah cara mengajar menggunakan Pendekatan Pendidikan Realistik Matematika Indonesia (PMRI) dengan menggunkan konteks nasi tumpeng.

Materi bangun ruang merupakan salah satu materi yang terdapat pada kurikulum 2013. Kurikulum 2013 memuat wawasan global, bukan hanya nasional maupun lokal dan membawa peserta didik mampu mengumpulkan informasi sebanyak mungkin. Pada Kurikulum 2013 Matematika di Sekolah Menengah Pertama (SMP) dalam Permendiknas RI No. 22 Tahun 2006 tentang Kerangka dan Struktur Kurikulum SMP/MTS menyatakan bahwa kurikulum adalah perangkat mata pelajaran dan program pendidikan yang berisi sebuah rancangan pelajaran yang akan diberikan kepada peserta didik dalam satu periode jenjang pendidikan. Sesuai dengan Permendiknas RI No. 22 Tahun 2006 disebutkan bahwa pendekatan pemecahan masalah merupakan fokus pembelajaran matematika yang mencakup masalah tertutup dengan solusi tidak tunggal dan masalah dengan berbagai cara penyelesaian. Untuk meningkatkan kemampuan memecahkan masalah perlu dikembangkan 
96| Rahmadona, Indrayanti, dan Widyaningrum: Efektifitas Pendekatan PMRI dengan...

keterampilan untuk memahami masalah, membuat model matematika, menyelesaikan masalah, dan menafsirkan solusinya. Kurikulum 2013 lebih membuat siswa yang berperan aktif, sedangkan guru melihat kegiatan siswa sehingga siswa dapat menyelesaikan masalah dan menemukan konsep matematika. Salah satu pendekatan pembelajaran yang sesuai dengan kurikulum 2013 adalah pendekatan PMRI, dimana matematika itu harus dekat dengan siswa dan relevan dengan situasi kehidupan siswa sehari-hari. Situasi kehidupan siswa bukan hanya sebatas apa yang nyata pada pandangan siswa tetapi juga semua hal yang dapat dibayangkan siswa, terjangkau oleh imajinasinya.

Menurut Abidin (2014), salah satu pendekatan pembelajaran yang membimbing dan memberikan kesempatan untuk siswa lebih aktif dalam pembelajaran matematika adalah Pendekatan Pendidikan Matematika Realistik Indonesia (PMRI). Pendidikan Matematika Realistik Indonesia bertitik tolak dari konteks atau situasi "real" yang pernah dialami oleh siswa yang merupakan jembatan untuk menghubungkan siswa dari tahap real ke dalam model matematika. Model matematika tersebut bertujuan untuk membangun ataupun menemukan kembali suatu konsep matematika melalui proses matematisasi. Proses matematisasi bisa diartikan sebagai proses me"matematika"kan dan menerjemahkan suatu konteks menjadi konsep matematika.

Menurut Feriana (2016) menyatakan pembelajaran menggunakan cara Filling dan Packing pada materi volume kubus dan balok dengan pendekatan PMRI membuat siswa lebih aktif dalam pembelajaran. Menurut Tri Pujiastuti (2017) menyatakan bahwa pembelajaran dengan pendekatan Realistic Mathematics Education (RME) dapat meningkatkan aktivitas belajar siswa pada materi bangun ruang sisi lengkung. Sedangkan menurut Suprijono (2009) menyatakan bahwa pembelajaran matematika dengan PMRI dan pelatihan metakognitif lebih unggul dalam meningkatkan kemampuan pemecahan masalah siswa dibandingkan dengan pendekatan konvensional. Jadi, dapat disimpulkan bahwa kelebihan pembelajaran matematika dengan menggunakan pendekatan PMRI adalah siswa menjadi lebih aktif dalam memecahkan masalah yang ada dalam pembelajaran matematika. 
Hasil penelitian sebelumnya Juwita (2015) menunjukkan bahwa peran alat peraga berupa buah semangka dapat mendukung siswa untuk mengembangkan pengetahuan mereka tentang konsep volume bola dan dapat meningkatkan pemahaman siswa pada materi volume bola sehingga proses pembelajaran volume bola tersebut menjadi bermakna. Hasil penelitian sebelumnya Yuliana (2017) menunjukkan bahwa perangkat pembelajaran yang dihasilkan memenuhi kriteria valid, praktis dan efektif. Perangkat pembelajaran yang dihasilkan valid berdasarkan pada penilaian dari ahli materi, ahli media dan guru matematika dengan skor rata-rata sebesar 4,46 untuk RPP dan 4,19 untuk LKS dengan skor maksimum 5,00. Perangkat pembelajaran yang dihasilkan praktis berdasarkan pada rata-rata keterlaksanaan pembelajaran sebesar $96,92 \%$ dengan kriteria praktis dan skor rata-rata angket respon siswa sebesar 2,93 dari skor rata-rata maksimal 4,00. Perangkat pembelajaran yang dihasilkan efektif berdasarkan pada hasil tes evalusi hasil belajar siswa dengan persentase ketuntasan belajar mencapai $75 \%$.

Berdasarkan uraian di atas, penelitian ini bertujuan untuk mengetahui keefektivan pendekatan PMRI dengan konteks nasi tumpeng pada materi volume kerucut terhadap hasil belajar siswa di kelas IX.

\section{METODE PENELITIAN}

Penelitian ini menggunakan pendekatan penelitian kuantitatif. Menurut Sugiyono (2015: 14-15), metode penelitian kuantitatif digunakan untuk meneliti pada populasi atau sampel tertentu. Teknik pengambilan sampel pada umumnya dilakukan secara random. Pengumpulan data menggunakan instrumen penelitian yaitu tes dan dokumentasi. Tes digunakan untuk mengetahui pencapaian hasil belajar siswa setelah menggunakan pendekatan PMRI dengan konteks nasi tumpeng pada materi volume kerucut. Tes yang diberikan berupa soal uraian sebanyak 5 (lima) soal. Tes diberikan sebelum melaksanakan (pretest) pembelajaran dan sesudah melaksanakan pembelajaran (posttest).

Analisis data bersifat kuantitatif/statistik dengan tujuan untuk menguji hipotesis yang telah ditetapkan. Dalam penelitian ini dilakukan 
98| Rahmadona, Indrayanti, dan Widyaningrum: Efektifitas Pendekatan PMRI dengan...

uji normalitas, uji homogenitas, dan uji hipotesis. Uji hipotesis dalam penelitian ini digunakan untuk menghitung perbedaan antara kelompok eksperimen yang diberi perlakuan dengan menggunakan pendekatan PMRI dengan konteks nasi tumpeng dan kelompok kontrol yang tidak diberi perlakuan dengan menggunakan pembelajaran biasa atau diskusi kelompok.

Desain dalam penelitian ini adalah eksperimen. Bentuk desain eksperimen yang digunakan dalam penelitian ini adalah TrueExperimental Design dengan bentuk desain pretest-posttest control group design.

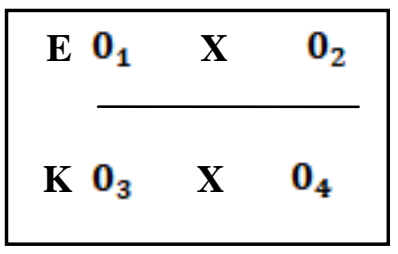

Penelitian ini dilaksanakan selama 2 minggu mulai dari tanggal 13 Maret 2019 sampai tanggal 30 Maret 2019. Objek penelitian ini adalah siswa kelas IX SMP Negeri 1 Pagaralam.

\section{HASIL PENELITIAN DAN PEMBAHASAN}

Berdasarkan hasil penelitian yang dilakukan hasil belajar siswa SMP Negeri 1 Pagaralam ada perbedaan antara kelas yang diajarkan menggunakan pendekatan PMRI dengan konteks nasi tumpeng dan yang tidak menggunakan pendekatan PMRI dengan konteks nasi tumpeng, nilai rata- rata siswa lebih baik dibandingkan siswa tanpa menggunakan pendekatan PMRI dengan konteks nasi tumpeng efektif terhadap hasil belajar pada materi volume kerucut dapat dilihat dari nilai rata-rata siswa kelas eksperimen yaitu $\vec{x}_{1}=76,09$ dan kelas kontrol $\vec{x}_{2}=61,92$.

Sehingga hipotesis dalam penelitian ini, penggunaan Pendekatan PMRI dengan konteks nasi tumpeng pada materi volume kerucut efektif terhadap hasil belajar siswa di kelas IX SMP Negeri 1 Pagaralam Tahun Pelajaran 2017/2018 dan dapat diterima kebanarannya. Hal ini dibuktikan 
berdasarkan perhitungan statistik hitung $\mathrm{t}_{\text {hitung }}=3,12$ dan $\mathrm{t}_{\text {tabel }}=1,69$ yang menunjukan $t_{\text {hitung }}>t_{\text {tabel. }}$.

Pembelajaran matematika menggunakan pendekatan PMRI dengan konteks nasi tumpeng terhadap hasil belajar siswa, yaitu:

1. Peneliti membagi siswa ke dalam 5 kelompok yang terdiri dari 6 orang. Setiap kelompok diminta untuk mengamati konteks yaitu nasi tumpeng;

2. Peneliti membagikan konteks yaitu nasi tumpeng dan alat peraga yang telah disediakan peneliti. Peneliti juga membagikan peraga tabung, kerucut, dan Lembar Kerja Peserta Didik (LKPD) kepada siswa. Kemudian setiap kelompok diminta untuk mengamati konteks tersebut yaitu nasi tumpeng dan menuliskannya di LKPD sesuai dengan petunjuk. Siswa mulai mengamati konteks dan mulai melakukan percobaan dengan mengisi nasi dari tabung ke kerucut untuk mendapatkan rumus dari volume kerucut menggunakan pendekatan PMRI dengan konteks nasi tumpeng dan kemudian menyimpulkannya ke dalam LKPD yang telah disediakan.

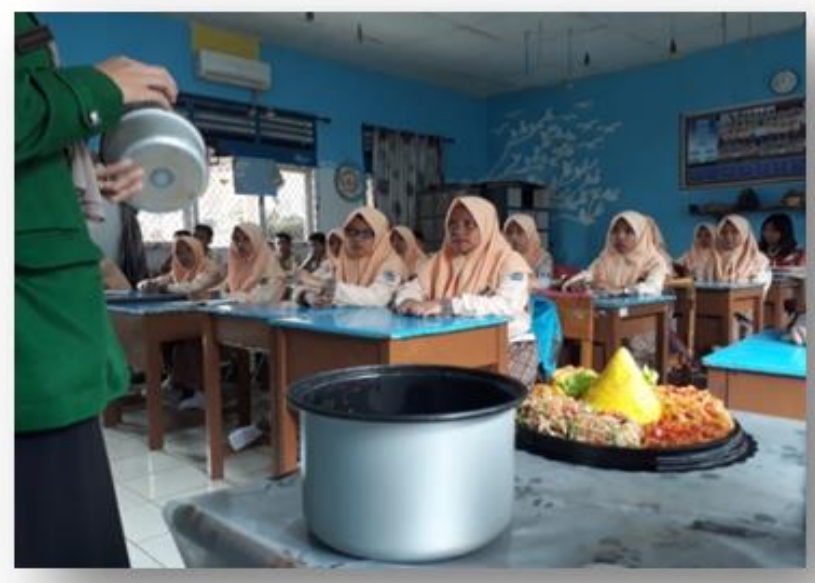

Gambar 1. Siswa Mengamati Nasi Tumpeng dan Alat Peraga 


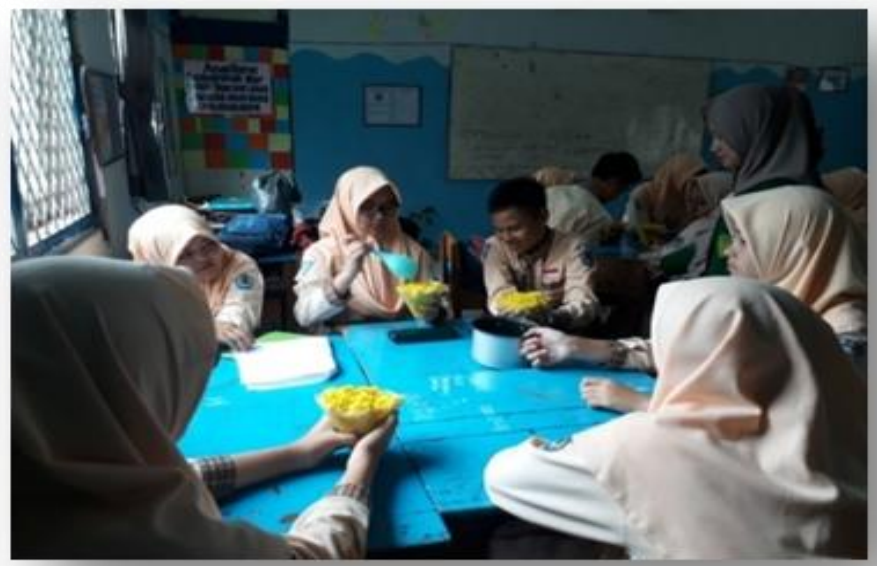

\section{Gambar 2. Siswa Mulai Melakukan Percobaan}

Kegiatan terakhir, peneliti meminta siswa untuk melengkapi LKPD bersama kelompoknya masing-masing.

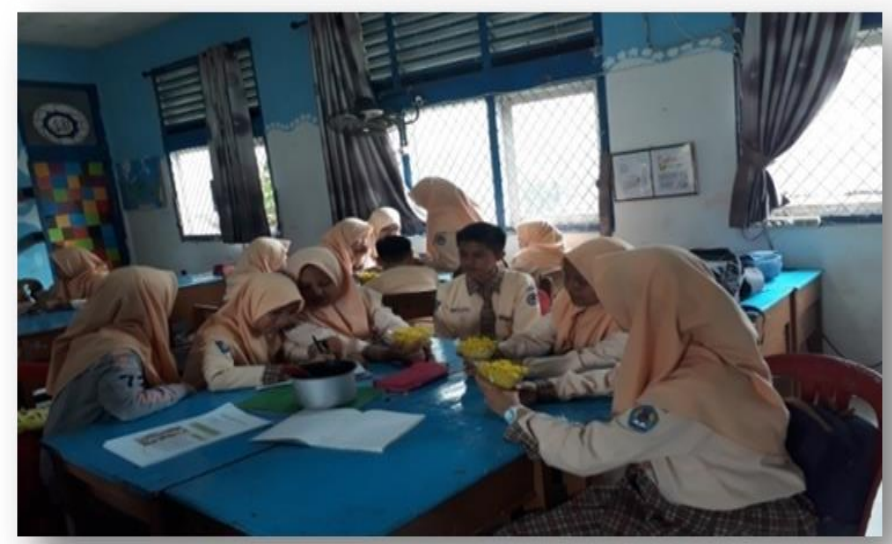

Gambar 3. Siswa Mengerjakan LKPD

Dari hasil pretest kelas kontrol diperoleh $\overline{\mathrm{x}}=54,5$ dan nilai ratarata posttest kelas kontrol diperoleh $\overline{\mathrm{x}}=61,92$, sedangkan hasil pretest 
rata-rata kelas eksperimen $\overline{\mathrm{x}}=60,5$, diperoleh nilai rata-rata posttest kelas eksperimen $\overline{\mathrm{x}}=76,09$.

\section{SIMPULAN}

Dengan menggunakan pendekatan PMRI dengan konteks nasi tumpeng pada materi volume kerucut, hasil belajar siswa pada kelas eksperimen lebih baik dibandingkan dengan hasil belajar siswa pada kelas kontrol. Hal ini dapat dilihat dari nilai rata - rata siswa kelas eksperimen (IX $\mathrm{F}_{\mathrm{F}}$ yaitu 76,09, maka dapat dikatakan bahwa hasil belajar mencapai KKM yang telah ditentukan sebesar 67. Sedangkan nilai rata - rata siswa kelas kontrol (IXI) yaitu 61,92 dapat ditentukan belum berhasil karena belum mencapai KKM yaitu 67.

Diperoleh $t_{\text {hitung }}>t_{(1-\kappa)}$ yaitu $3,12>1,69$ yang berarti

$t_{\text {hitung }}>t_{\text {tabel }}$, maka $\mathrm{H}_{0}$ ditolak dan $\mathrm{H}_{\mathrm{a}}$ diterima sehingga Pendekatan PMRI dengan Konteks Nasi Tumpeng Efektif terhadap Hasil Belajar Siswa Kelas IX SMP Negeri 1 Pagaralam Tahun Pelajaran 2018/2019.

\section{DAFTAR PUSTAKA}

Arikunto, S. (2013). Prosedur Penelitian Suatu Pendekatan Praktek. Jakarta: Rineka Cipta.

Curry, M., \& Outhered, L. (2005). Conceptual Understanding of Spatial Measurement. Building Connections: Theory, Researchand Practice, 265-272.

Depdiknas. (2006). Kamus Besar Bahasa. Jakarta: Balai Pustaka.

Hamalik, O. (2011). Kurikulum dan Pembelajaran. Jakarta: Bumi Aksara. Irmayanti., L. W. (2018). Peningkatan Hasil Belajar Matematika Materi Bangun Ruang Sisi Lengkung dengan Model Problem Based Learning (PBL) pada Siswa Kelas IX E SMP Negeri 1 Margasari Semester Ganjil Tahun Pelajaran 2016/2017. Jurnal Dialektika Pembelajaran Matematika, 5(1), 47-59. Retrieved from https://journal.peradaban.ac.id/index.php/jdpmat/article/view/282. 
102| Rahmadona, Indrayanti, dan Widyaningrum: Efektifitas Pendekatan PMRI dengan...

Juwita., H. (2015). Peranan Buah Semangka dalam Pembelajaran. Jurnal Elemen, 1(2), No page. Retrieved from https://www.google.co.id/url?sa=t\&rct=j\&q=\&esrc=s\&source=web\& $\mathrm{cd}=2 \& v e d=2$ ahUKEwj2_-

HtgpvmAhVRX30KHTmzCFUQFjABegQIAxAD\&url=http\%3A\%2 $\mathrm{F} \% 2 \mathrm{Fe}-$

journal.hamzanwadi.ac.id\%2Findex.php\%2Fjel\%2Farticle\%2Fview \%2F145\%2F120\&usg=AOvVaw35XcIzvkQkHh9X8gXonMBr.

Sumantri., M. S. (2016). Strategi Pembelajaran Teori dan Praktik di Tingkat Pendidikan Dasar. Jakarta: Rajawali Pers.

Syahbana.A. (2013). Alternatif Pemahaman Konsep Umum Volume Suatu Bangun Ruang. Jurnal Edumatica, 3(2), 1-7. Retrieved from https://online-journal.unja.ac.id/index.php/edumatica/article/view/ 2662

Wijaya, A. (2012). Pendidikan Matematika Realistik Suatu Alternatif Pendekatan Pembelajaran Matematika. Yogyakarta: Graha Ilmu.

Yuliana., R. (2017). Pengembangan Perangkat Pembelajaran dengan Pendekatan PMRI pada Materi Bangun Ruang Sisi Lengkung. Jurnal Pendidikan Matematika, 6(1), 60-67. Retrieved from http://journal.student.uny.ac.id/ojs/index.php/pmath/article/view/597 4. 